\title{
The 2015 European heat wave
}

Article

Published Version

Dong, B., Sutton, R., Shaffrey, L. and Wilcox, L. (2016) The 2015 European heat wave. Bulletin of the American Meteorological Society, 97. S57-S62. ISSN 1520-0477 doi: https://doi.org/10.1175/BAMS-D-16-0140.1 Available at https://centaur.reading.ac.uk/68490/

It is advisable to refer to the publisher's version if you intend to cite from the work. See Guidance on citing.

To link to this article DOI: http://dx.doi.org/10.1175/BAMS-D-16-0140.1

Publisher: American Meteorological Society

All outputs in CentAUR are protected by Intellectual Property Rights law, including copyright law. Copyright and IPR is retained by the creators or other copyright holders. Terms and conditions for use of this material are defined in the End User Agreement.

www.reading.ac.uk/centaur

\section{CentAUR}

Central Archive at the University of Reading

Reading's research outputs online 


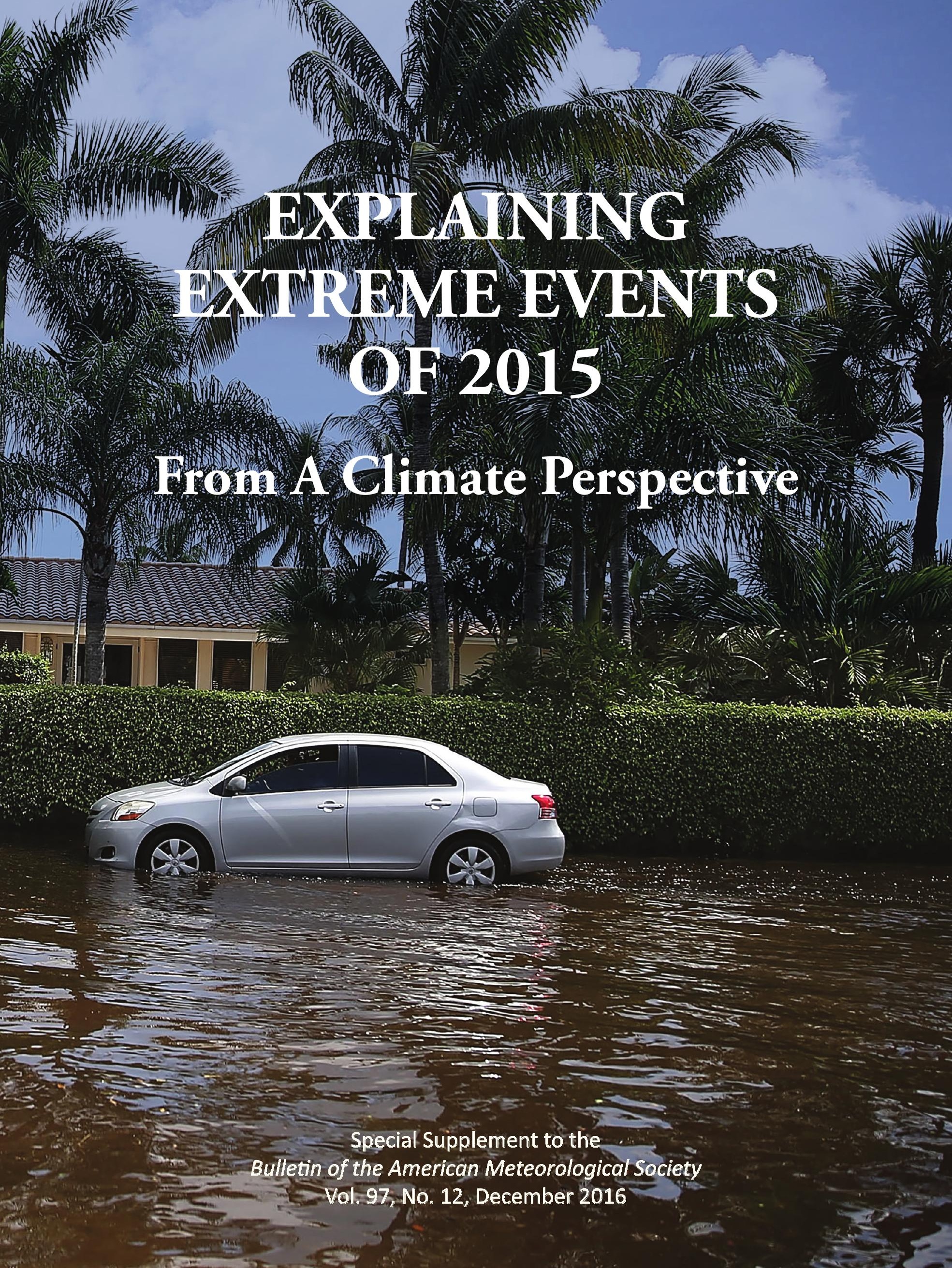




\section{EXPLAINING EXTREME \\ EVENTS OF 20I5 FROM A CLIMATE PERSPECTIVE}

\section{Editors}

Stephanie C. Herring, Andrew Hoell, Martin P. Hoerling, James P. Kossin, Carl J. Schreck III, and Peter A. Stott

Special Supplement to the

Bulletin of the American Meteorological Society

Vol. 97, No. I2, December 2016 


\section{CORRESPONDING EDITOR:}

Stephanie C. Herring, PhD

NOAA National Centers for Environmental Information

325 Broadway, E/CC23, Rm IB-I3I

Boulder, CO, 80305-3328

E-mail: stephanie.herring@noaa.gov

\section{Cover CRedit:}

CPhoto by Joe Raedle/Getty Images-A vehicle drives through flooded streets caused by a combination of the lunar orbit which caused seasonal high tides and what many believe is the rising sea levels due to climate change on September 30, 20I5, in Fort Lauderdale, Florida. South Florida is projected to continue to feel the effects of climate change, and many of the cities have begun programs such as installing pumps or building up sea walls to try and combat the rising oceans.

\section{HOW TO CITE THIS DOCUMENT}

Citing the complete report:

Herring, S. C., A. Hoell, M. P. Hoerling, J. P. Kossin, C. J. Schreck III, and P.A. Stott, Eds., 20I6: Explaining Extreme Events of 20 I5 from a Climate Perspective. Bull.Amer. Meteor. Soc., 97 (I 2), SI-SI 45.

Citing a section (example):

Partain, J. L., and Coauthors, 2016: An assessment of the role of anthropogenic climate change in the Alaska fire season of 2015 [in "Explaining Extremes of 2015 from a Climate Perspective”]. Bull. Amer. Meteor. Soc., 97 (I2), SI4-SI8, doi:I0.II75/BAMS-D-16-0149.

\section{EDITORIAL AND PRODUCTION TEAM}

Riddle, Deborah B., Lead Graphics Production, NOAA/NESDIS National Centers for Environmental Information,

Asheville, NC

Veasey, Sara W., Visual Communications Team Lead, NOAA/ NESDIS National Centers for Environmental Information, Asheville, NC

Love-Brotak, S. Elizabeth, Graphics Support, NOAA/NESDIS National Centers for Environmental Information,

Asheville, NC

Fulford, Jennifer, Editorial Support, Telesolv Consulting LLC, NOAA/NESDIS National Centers for Environmental Information, Asheville, NC

Griffin, Jessicca, Graphics Support, Cooperative Institute for Climate and Satellites-NC, North Carolina State University, Asheville, NC
Maycock, Tom, Editorial Support, Cooperative Institute for Climate and Satellites-NC, North Carolina State University, Asheville, NC

Misch, Deborah J., Graphics Support, Telesolv Consulting LLC, NOAA/NESDIS National Centers for Environmental Information, Asheville, NC

Osborne, Susan, Editorial Support, Telesolv Consulting LLC, NOAA/NESDIS National Centers for Environmental Information, Asheville, NC

Sprain, Mara, Editorial Support, LAC Group, NOAA/NESDIS National Centers for Environmental Information, Asheville, NC

Young, Teresa, Graphics Support, STG, Inc., NOAA/NESDIS National Centers for Environmental Information, Asheville, NC 


\section{TABLE OF CONTENTS}

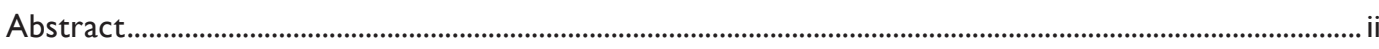

I. Introduction to Explaining Extreme Events of 2015 from a Climate Perspective.................................

2. Multimodel Assessment of Anthropogenic Influence on Record Global and Regional Warmth

During 2015 ........................................................................................................................................

3. What History Tells Us About 2015 U.S. Daily Rainfall Extremes ......................................................

4. An Assessment of the Role of Anthropogenic Climate Change in the Alaska Fire Season

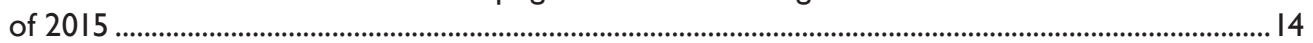

5. The 2014/15 Snowpack Drought in Washington State and its Climate Forcing ................................19

6. In Tide's Way: Southeast Florida's September 2015 Sunny-day Flood ................................................... 25

7. Extreme Eastern U.S. Winter of 2015 Not Symptomatic of Climate Change .....................................

8. The Role of Arctic Sea Ice and Sea Surface Temperatures on the Cold 2015 February

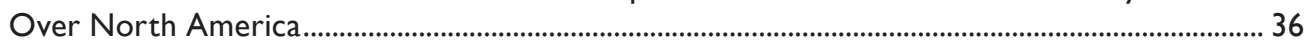

9. The 2015 Extreme Drought in Western Canada ................................................................................ 42

10. Human Contribution to the Record Sunshine of Winter 2014/15 in the United Kingdom .............47

II. The Role of Anthropogenic Warming in 2015 Central European Heat Waves ...................................5I

12. The 2015 European Heat Wave ....................................................................................................................

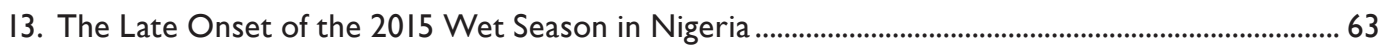

14. Human Influences on Heat-Related Health Indicators During the 2015 Egyptian Heat Wave .................................................................................................................................. 70

15. Assessing the Contributions of Local and East Pacific Warming to the 2015

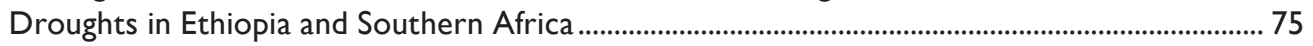

16. The Deadly Combination of Heat and Humidity in India and Pakistan in Summer 2015..................8I

17. The Heavy Precipitation Event of December 2015 in Chennai, India................................................... 87

18. Attribution of Extreme Rainfall in Southeast China During May 2015 ............................................. 92

19. Record-Breaking Heat in Northwest China in July 2015: Analysis of the Severity and Underlying Causes ........................................................................................................................... 97

20. Human Influence on the 2015 Extreme High Temperature Events in Western China................... 102

21. A Persistent Japanese Heat Wave in Early August 2015: Roles of Natural Variability and

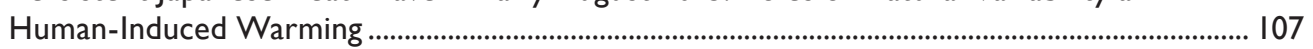

22. Climate Change and El Niño Increase Likelihood of Indonesian Heat and Drought........................ 113

23. Southern Australia's Warmest October on Record: The Role of ENSO and Climate Change....................................................................................................................................... 118

24. What Caused the Record-Breaking Heat Across Australia in October 2015? .............................. 122

25. The Roles of Climate Change and El Niño in the Record Low Rainfall in October 2015 in Tasmania, Australia.

26. Influences of Natural Variability and Anthropogenic Forcing on the Extreme 2015 Accumulated Cyclone Energy in the Western North Pacific

27. Record Low Northern Hemisphere Sea Ice Extent in March 2015 ............................................... 136

28. Summary and Broader Context.....................................................................................................141 
This fifth edition of explaining extreme events of the previous year (2015) from a climate perspective continues to provide evidence that climate change is altering some extreme event risk. Without exception, all the heat-related events studied in this year's report were found to have been made more intense or likely due to human-induced climate change, and this was discernible even for those events strongly influenced by the $2015 \mathrm{El}$ Niño. Furthermore, many papers in this year's report demonstrate that attribution science is capable of separating the effects of natural drivers including the strong 2015 El Niño from the influences of long-term human-induced climate change.

Other event types investigated include cold winters, tropical cyclone activity, extreme sunshine in the United Kingdom, tidal flooding, precipitation, drought, reduced snowpack in the U.S. mountain west, arctic sea ice extent, and wildfires in Alaska. Two studies investigated extreme cold waves and monthly-mean cold conditions over eastern North America during 2015, and find these not to have been symptomatic of human-induced climate change. Instead, they find the cold conditions were caused primarily by internally generated natural variability. One of these studies shows winters are becoming warmer, less variable, with no increase in daily temperature extremes over the eastern United States. Tropical cyclone activity was extreme in 2015 in the western North Pacific (WNP) as measured by accumulated cyclone energy (ACE). In this report, a study finds that human-caused climate change largely increased the odds of this extreme cyclone activity season. The 2015 Alaska fire season burned the second largest number of acres since records began in 1940. Investigators find that human-induced climate change has increased the likelihood of a fire season of this severity.

Confidence in results and ability to quickly do an attribution analysis depend on the "three pillars" of event attribution: the quality of the observational record, the ability of models to simulate the event, and our understanding of the physical processes that drive the event and how they are being impacted by climate change. A result that does not find a role for climate change may be because one or more of these three elements is insufficient to draw a clear conclusion. As these pillars are strengthened for different event types, confidence in the presence and absence of a climate change influence will increase.

This year researchers also link how changes in extreme event risk impact human health and discomfort during heat waves, specifically by looking at the role of climate change on the wet bulb globe temperature during a deadly heat wave in Egypt. This report reflects a growing interest within the attribution community to connect attribution science to societal impacts to inform risk management through "impact attribution." Many will watch with great interest as this area of research evolves in the coming years. 


\title{
12. THE 20I5 EUROPEAN HEAT WAVE
}

\author{
Buwen Dong, Rowan Sutton, Len Shaffrey, and Laura Wilcox
}

A heat wave swept across central Europe in summer 2015. Model experiments suggest that anthropogenic forcings were a major factor in setting the conditions for the development of the 2015 heat wave.

Observations. An extreme summer heat wave set temperature records across Europe during June and July. On 1 July, London experienced its hottest July maximum temperature on record: $36.7^{\circ} \mathrm{C}$. Paris recorded its second hottest day ever on 2 July, with a high temperature of $39.7^{\circ} \mathrm{C}$, and Berlin experienced its highest temperature on record, $37.9^{\circ} \mathrm{C}$, on 4 July (BBC News 1 July 2015; Liberto 2015). Averaged over central Europe (Fig. 12.1a), the seasonal mean (June-August) surface air temperature (SAT) anomaly was $2.40^{\circ} \mathrm{C}$ above the $1964-93$ mean: 3.65 standard deviations of the interannual variability. This magnitude of warming is comparable with previous hot summers in Europe, such as 2003 (e.g., Schaer et al. 2004; Christidis et al. 2015) and 2010 (e.g., Barriopedro et al. 2011; Otto et al. 2012) when summer mean SAT anomalies over the same region were $2.38^{\circ} \mathrm{C}$ and $2.42^{\circ} \mathrm{C}$ (3.63 and 3.68 standard deviations), respectively. In addition to the very hot mean SAT, records over central Europe were set for some temperature extremes: the annual hottest day temperature (TXx), seasonal mean daily maximum temperature (Tmax), and diurnal temperature range (DTR) were $4.04^{\circ}, 3.04^{\circ}$, and $1.53^{\circ} \mathrm{C}$ above the $1964-93$ mean. The 2015 summer extreme hot temperature occurred in the context of a decade of summer warming and increases in hot temperature extremes, and in fact, 2015 was the driest and the second hottest summer in recent decades (Figs. 12.1a,b).

The observed spatial patterns of 2015 anomalies in SAT and temperature extremes, relative to the 1964-93 mean, indicate coherent positive anomalies over central Europe, but weak negative anomalies over northern Europe (Figs. 12.1c-h). These temperature anomalies are associated with an

AFFILIATIONS: DONG, SUTTON, ShafFReY, AND WILCOXNational Centre for Atmospheric Science, Department of Meteorology, University of Reading, Reading, United Kingdom

DOI:I0.II75/BAMS-D-16-0140.I

A supplement to this article is available online ( 10.1175 /BAMS-D-16-0140.2) anomalous anticyclonic circulation (not shown) and reduced precipitation over central Europe and a weak increase over northern Europe (Supplemental Figs. S12.1b,g). Importantly, the magnitude of changes in Tmax and TXx is about twice that in seasonal mean daily minimum temperature (Tmin) and the annual hottest night temperature (TNx), suggesting an important role of land-atmosphere-cloud feedbacks associated with the precipitation deficit over central Europe in summer. This results in a reduction of evaporation and cloud cover associated with soil drying, enhancing Tmax and TXx more than Tmin and TNx through increased daytime downward shortwave radiation and decreased daytime upward latent heat flux (Vautard et al. 2007; Fischer and Schär 2010; Mueller and Seneviratne 2012; Boé and Terray 2014; Miralles et al. 2014; Perkins 2015; Dong et al. 2016). Precipitation anomalies in the winter and spring seasons before summer 2015 were much smaller than in summer over central Europe (not shown). This implies the land-atmosphere-cloud feedback on the 2015 European heat wave was mainly through simultaneous precipitation deficit rather than a presummer deficit over central Europe.

What caused these anomalous summer conditions over central Europe in 2015? Relative to the 1964-93, warm sea surface temperatures (SSTs) were present in many regions (Fig. 12.1i), with a prominent warm anomaly $\left(>1.2^{\circ} \mathrm{C}\right)$ in the tropical Pacific during the developing phase of the exceptionally strong 2015/16 El Niño (WMO 2016). There were also SST anomalies along the Gulf Stream extension in the North Atlantic with a cooling to the north and warming to the south. Associated with this feature is an enhanced meridional SST gradient along the Gulf Stream extension. This might have favored a northward shift of the North Atlantic summer storm track (e.g., Ogawa et al. 2012; Dong et al. 2013a and 2013b; Duchez et al. 2016), which would result in reduced precipitation in summer 2015 over central Europe (Supplemental Fig. S12.1g). The large warming in the 
(a) 4

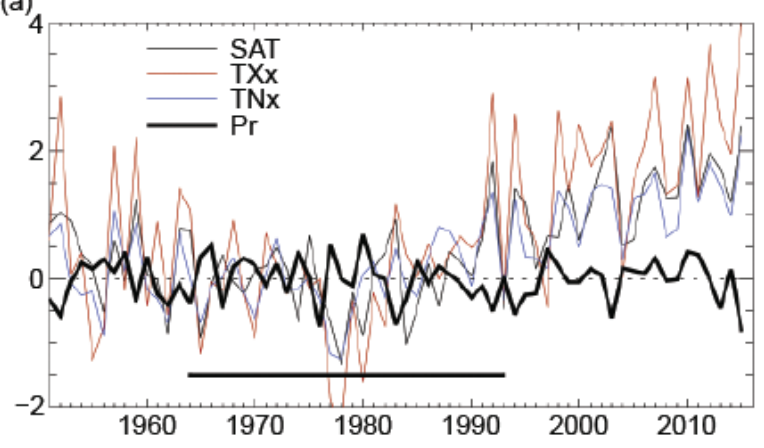

(c)
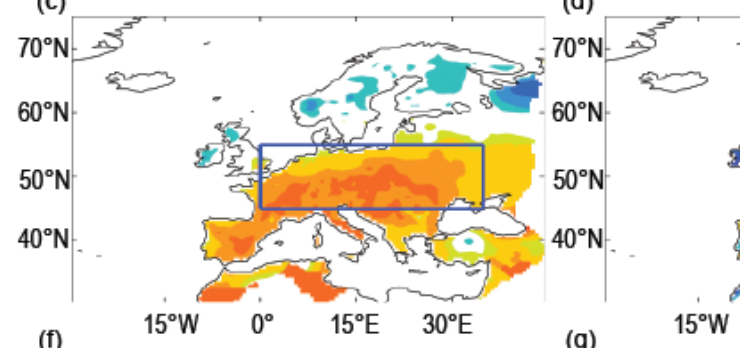

(b)

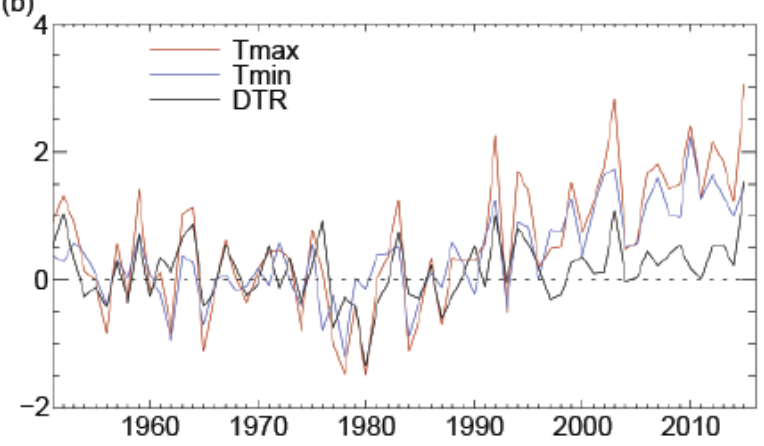

(e)
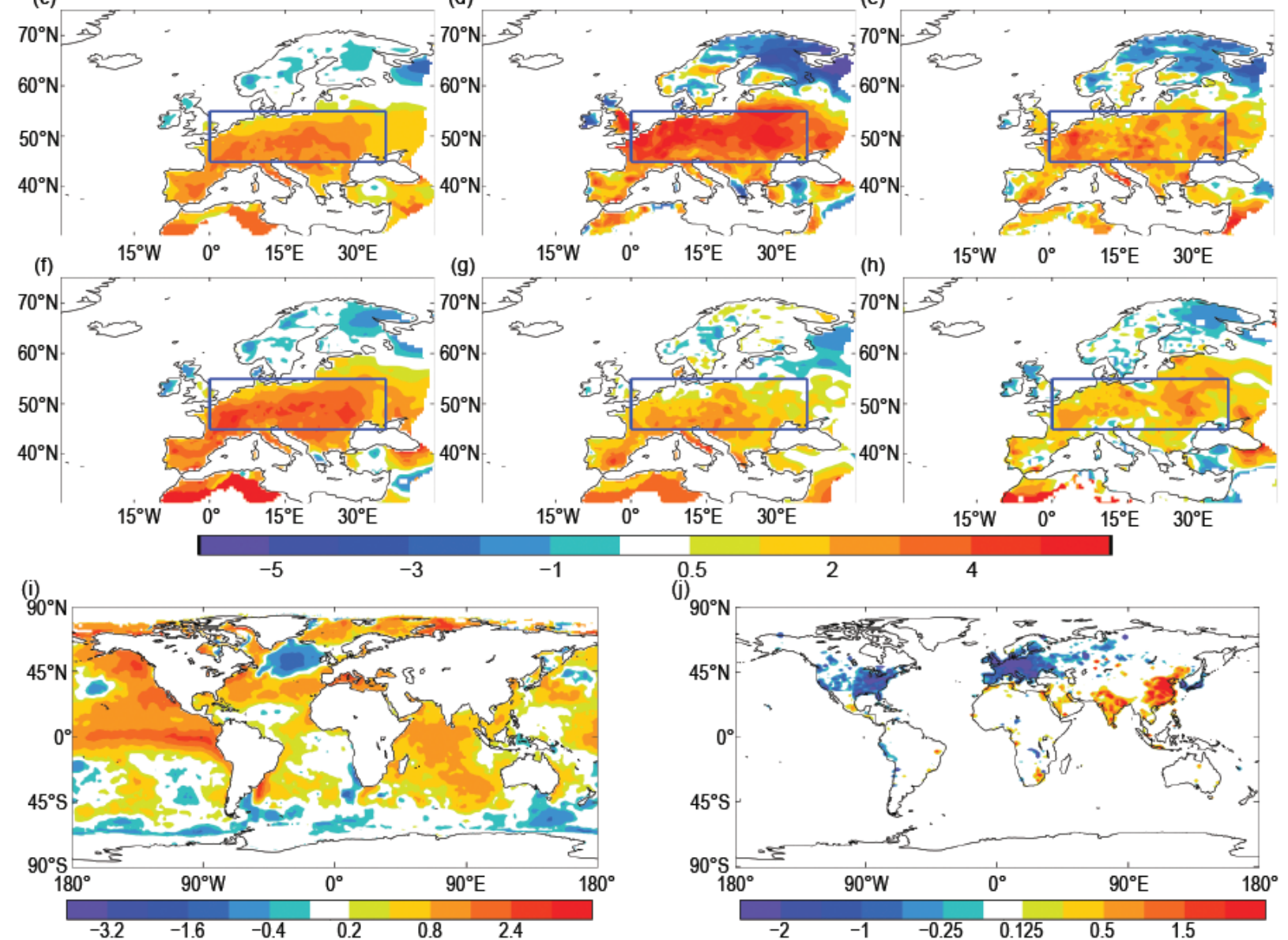

(h)

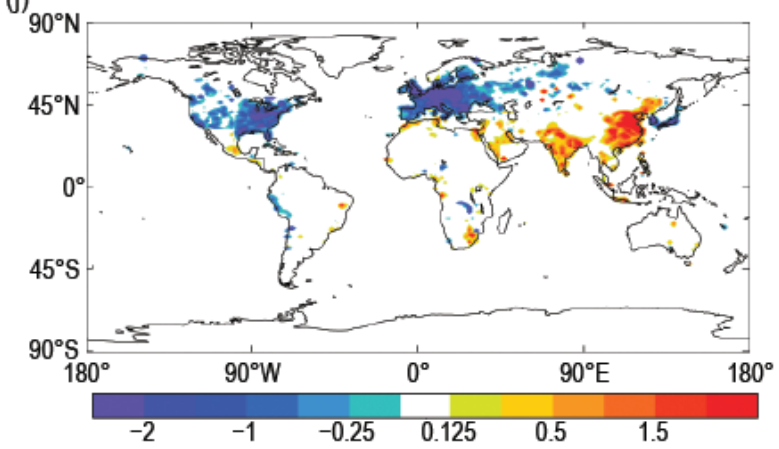

FIG. I2.I. (a),(b) Time series and (c)-(h) spatial patterns of summer or annual anomalies relative to $1964-93$ [black bar in (a)] climatology. (a),(b) Time series averaged over central Europe $\left[45^{\circ}-55^{\circ} \mathrm{N}, 0^{\circ}-35^{\circ} \mathrm{E}\right.$, land only, blue box in (c)-(h)]. (c)-(h) Spatial patterns of 2015 anomalies in summer mean SAT, TXx, TNx, summer mean Tmax, Tmin, and DTR from the gridded E-OBS dataset (version I2.0; Haylock et al. 2008). (i) Spatial patterns of 2015 summer SST anomalies relative to 1964-93. (j) Changes in annual mean sulphur dioxide emissions ( $g$

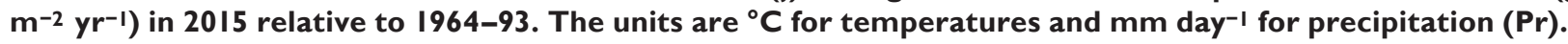

Arctic might also be a factor for the 2015 summer heat wave (Coumou et al. 2015).

Climate model experiments. Relative to 1964-93, there were significant increases in greenhouse gas (GHG) concentrations (e.g., WMO 2015) and also significant changes in anthropogenic aerosol (AA) precursor emissions with reductions from Europe and North America and increases from Asia (Fig. 12.1j; Lamarque et al. 2010 and 2011). A set of climate model experiments has been carried out to identify the relative roles of changes in SST/sea ice extent (SIE) and 
anthropogenic forcings (GHG and AA) in shaping the 2015 European summer heat wave. In this study, we do not address the anthropogenic contribution to SST/SIE changes, but rather consider these changes as an independent forcing factor. We use the atmosphere configuration of the Met Office Hadley Centre Global Environment Model version 3 (HadGEM3-A; Hewitt et al. 2011), with a resolution of $1.875^{\circ}$ longitude by $1.25^{\circ}$ latitude and 85 vertical levels. The CONTROL experiment is performed for the period 1964-93. Two other experiments, 2015ALL and 2015SST, are performed for the period November 2014 to October 2015 , use 2015 SST/SIE boundary conditions, but they differ in the specification of GHG and AA forcings (Table 12.1). All experiments are 27 years long, with only the last 25 years used for analysis (as an ensemble of 25 one-year members).

The CONTROL experiment reproduces both the mean and interannual variability of summer SAT over central Europe, despite the fact that there is no interannual variability in SST/SIE, GHG, and AA (Supplemental Fig. S12.1a). However, there are biases in the simulated seasonal mean precipitation and some temperature extremes in CONTROL (Supplemental Figs. S12.1b-e). Precipitation is overestimated by 0.23 $\mathrm{mm}$ day $^{-1}$ ( $10 \%$ larger than observations), Tmax is underestimated by $1.5^{\circ} \mathrm{C}$, and Tmin is overestimated by $1.5^{\circ} \mathrm{C}$. As a result, seasonal mean SAT is similar to observations, but DTR is underestimated by about $3.0^{\circ} \mathrm{C}$ in CONTROL (a common bias in AGCMs and RGCMs; e.g., Kysely and Plavcova 2012; Cattiaux et al. 2015). The underestimation of Tmax, TXx, and DTR, and overestimation of Tmin and TNx (not shown) imply that the cloud cover over the region in the model might be overestimated, as suggested by the overestimation of area-averaged precipitation. Despite the mean biases in the temperature extremes, their interannual variability in the CONTROL experiment is in broad agreement with observations (Supplemental Figs. S12.1a-e).

In response to all forcing changes (2015ALL), the area-averaged summer warming over central Europe is $1.6^{\circ} \mathrm{C}$, compared to $2.4^{\circ} \mathrm{C}$ in observations (Fig. 12.2a). This implies that about $2 / 3$ of the observed summer warming might have been anticipated as a mean response to SST/SIE and anthropogenic forcing changes. Spatial patterns of changes in SAT and temperature extremes show some differences to observed changes (Figs. 12.1, and 12.2) with the large temperature changes in the model displaced eastward to eastern Europe. The model mean response shows warming and an increase in temperature extremes over both central and northern Europe (Figs. 12.2c-h), but does not capture the observed precipitation reduction over central Europe (not shown). Therefore, it is likely that the model is not capturing cloud and land surface feedbacks induced by precipitation changes, and thus underestimates the observed surface warming and changes in Tmax and TXx over central Europe by about $1 / 3$, while simulated changes in Tmin and TNx are similar in magnitude to observations (Fig. 12.2a). The SST/SIE changes have a relatively weak effect on SAT and hot extremes but lead to a considerable increase in Tmin and $\mathrm{TNx}$, likely related in part to water vapor feedback because increased water vapor in the atmosphere enhances the downward longwave radiation, which has a large impact on night temperatures (Dai et al. 1999; Dong et al. 2016). Quantitatively, SST/SIE changes explain $22.5 \%$ of the area-averaged central European warming signal in the model, with the remaining $77.5 \%$ explained by GHG and AA changes with an assumption that the responses to different forcings add linearly (Fig. 12.2b), indicating a dominant role for the direct impact of anthropogenic

Table I2.I. Summary of numerical experiments.

\begin{tabular}{|l|l|}
\hline Experiments & Boundary conditions \\
\hline CONTROL & $\begin{array}{l}\text { Forced with monthly mean climatological sea surface temperature (SST) and sea ice extent (SIE) aver- } \\
\text { aged over the period of } 1964 \text { to } 1993 \text { using HadISST data (Rayner et al. 2003), with greenhouse gas } \\
\text { (GHG) concentrations averaged over the same period, and anthropogenic aerosol (AA) precursor } \\
\text { emissions averaged over the period of } 1970 \text { to } 1993 \text { (Lamarque et al. 20I0). }\end{array}$ \\
\hline 20I5ALL & $\begin{array}{l}\text { Forced with monthly mean SST and SIE from November 20I4 to October 20I5 using HadISST data, } \\
\text { with GHG concentrations in 20I4 (WMO 20I5), and AA precursor emissions for 20I5 from RCP4.5 } \\
\text { scenario (Lamarque et al. 20II). }\end{array}$ \\
\hline 20I5SST & As 20I5ALL, but with GHG concentrations and AA precursor emissions the same as in CONTROL. \\
\hline
\end{tabular}


(a)

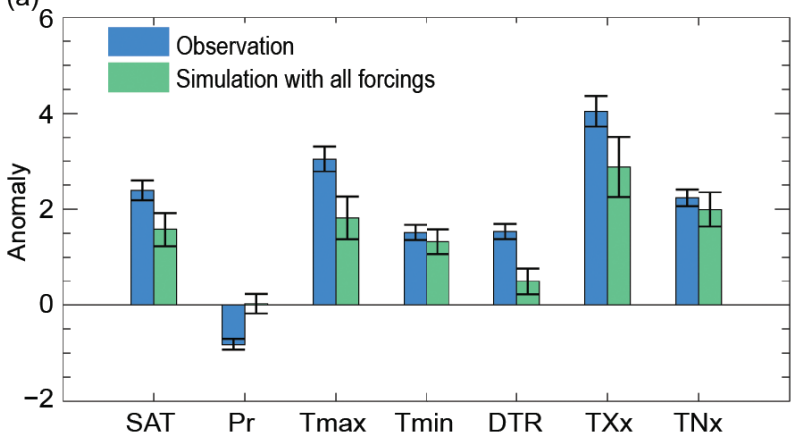

(c)

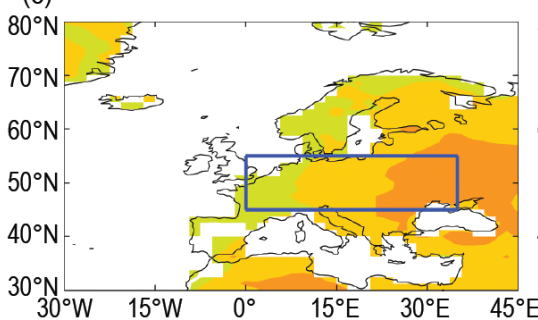

(d)

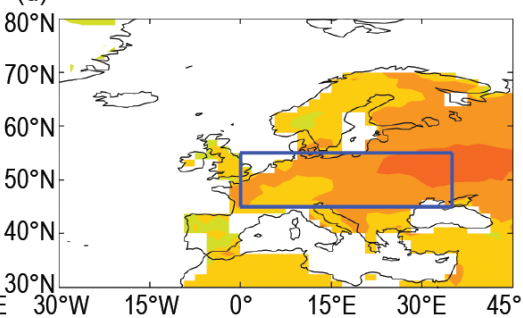

(g)

(f)

$80^{\circ} \mathrm{N}-0^{\circ} \mathrm{s}$

$60^{\circ} \mathrm{N}$

$40^{\circ} \mathrm{N}$.

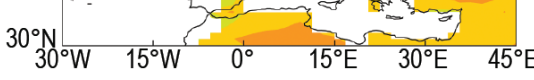

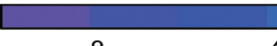

$-4$

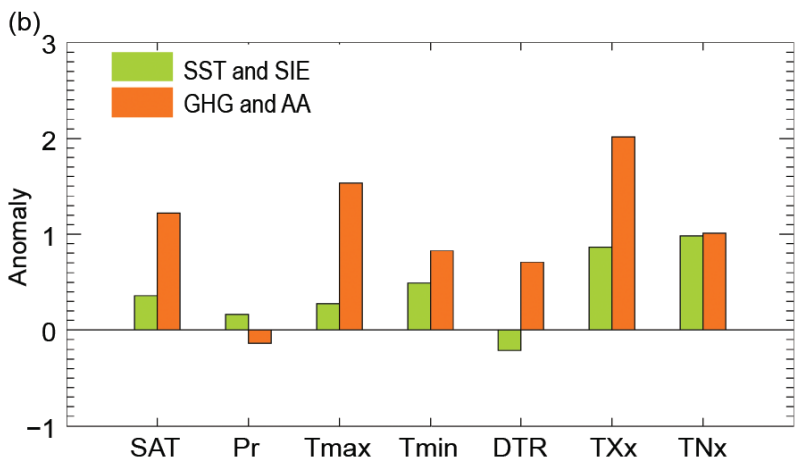

(e)

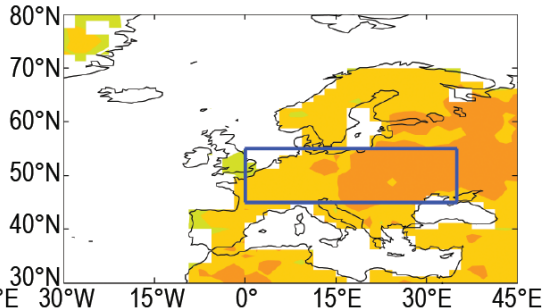

(h)

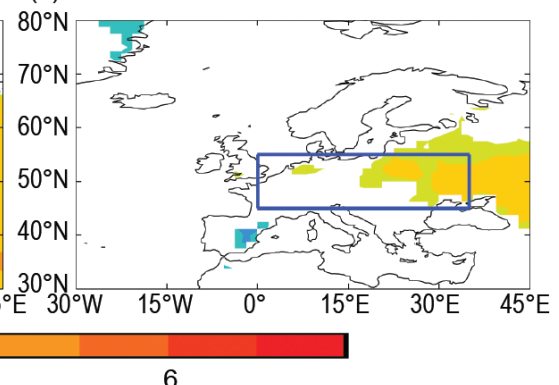

FIG. 12.2. (a) Observed and simulated 2015 anomalies for SAT, Pr (mm day-1), Tmax, Tmin, DTR, TXX, and TNx averaged over central Europe (land only) in response to changes in all forcings (20I5ALL-CONTROL). Colored bars indicate central estimates and whiskers show the $\mathbf{9 0 \%}$ confidence intervals based on a two-tailed Student's t-test. (b) Model responses to different forcings. SST and SIE: Response to changes in SST/SIE (20I5SST-CONTROL); GHG and AA: Response to changes in anthropogenic forcings (2015ALL-20I5SST). (c)-(h) Spatial patterns of changes in temperature and temperature extremes (SAT, TXx, TNx, Tmax, Tmin, and DTR) in response to all forcings (20I5ALL-CONTROL). Only changes that are statistically significant at the $90 \%$ confidence level are plotted in (c)-(h). The unit is ${ }^{\circ} \mathrm{C}$.

forcings in changes of summer SAT and temperature extremes in the model mean response (Fig. 12.2b; Supplemental Fig. S12.2).

The various model experiments exhibit substantial internal variability in simulated precipitation and temperature extremes (Supplemental Fig. S12.1). One particular year in 2015ALL exhibits a decrease (relative to CONTROL) of the area-averaged precipitation that is as large as the observed anomaly (Supplemental Fig. S12.1b). The magnitudes, relative to CONTROL, of the area-averaged summer SAT and temperature extremes in this driest year are very close to the observed anomalies (Supplemental Fig. S12.1f). Furthermore, the spatial patterns of simulated changes in SAT and precipitation also show good agreement with the observed patterns despite the eastward extension of large temperature anomalies in the simulation (Supplemental Figs. S12.1h,i). Interestingly, there are no such years in either the CONTROL or 2015SST simulation. This suggests that changes in SST/SIE and anthropogenic forcings set preconditions for an extremely dry year, such as summer 2015, to occur in the model simulation. The inability of the model to reproduce observed precipitation anomalies in the mean response, and the good agreement of changes in one particular year with observed anomalies in response to changes in all forcings, suggests that internal atmospheric variability might have played a significant role for the reduction in precipitation, and hence the severity of the 2015 European summer heat 
wave. Specifically, our simulations suggest internal variability contributed about $1 / 3$ of the observed summer warming and increases in hot temperature extremes over central Europe, in line with attributions of the severity of the 2010 Russian heat wave (e.g., Dole et al. 2011; Otto et al. 2012). However, it is important to recognize that the quantitative partitioning of causes is potentially sensitive to model biases, such as the mean wet bias discussed earlier.

Conclusions. Summer 2015 was marked by hot and dry conditions over central Europe and significant increases in temperature extremes. Model experiments indicate that high temperatures were caused by a combination of forced responses and internal atmospheric variability. Model simulations suggest that changes in SST/SIE and anthropogenic forcings explain about $2 / 3\left(1.6^{\circ} \mathrm{C}\right)$ of the observed warming $\left(2.4^{\circ} \mathrm{C}\right)$ and changes in hot temperature extremes over central Europe relative to 1964-93. Interestingly, when comparing 2015SST with 2015ALL simulations, the results indicate that the impact of anthropogenic forcings plays the dominant role. About $1 / 3\left(0.8^{\circ} \mathrm{C}\right)$ of the observed summer mean warming and changes in hot extremes is not explained by the model mean response and consequently may have resulted from internal variability, principally through physical processes associated with precipitation deficits. Thus, our results indicate that anthropogenic forcings set the conditions for the development of the 2015 heat wave in central Europe, but that internal variability was an important factor in explaining its extreme character.

ACKNOWLEDGEMENTS. This work was supported by EUCLEIA project funded by the European Union's Seventh Framework Programme [FP7/2007-2013] under Grant Agreement No. 607085 and by the U.K.-China Research and Innovation Partnership Fund through the Met Office Climate Science for Service Partnership China (CSSP China) as part of the Newton Fund. Authors are supported by the U.K. National Centre for Atmospheric Science-Climate at the University of Reading. HadISST and E-OBS gridded datasets are available from www.metoffice.gov.uk/hadobs/ and www.ecad.eu /download/ensembles/ensembles.php.

\section{REFERENCES}

Barriopedro, D., E. M. Fischer, J. Lutenbacher, R. M. Trigo, and R. Garcia-Herrera, 2011: The hot summer of 2010: Redrawing the temperature record map of Europe. Science, 332, 220-224.

BBC News, 2015: Hottest July day ever recorded in UK. BBC, 1 July 2015. [Available online at www.bbc .co.uk/news/uk-england-33324881.]

Boé, J., and L. Terray, 2014: Land-sea contrast, soilatmosphere and cloud-temperature interactions: interplays and roles in future summer European climate change. Climate Dyn., 42, 683-699.

Cattiaux, J., H. Douville, R. Schoetter, S. Parey, and P. Yiou, 2015: Projected increase in diurnal and interdiurnal variations of European summer temperatures. Geophys. Res. Lett., 42, 899-907, doi:10.1002/2014GL062531.

Christidis, N., G. S. Jones, and P. A. Stott, 2015: Dramatically increasing chance of extremely hot summers since the 2003 European heatwave. Nat. Climate Change, 5, 46-50.

Coumou, D., J. Lehmann, and J. Beckmann, 2015: The weakening summer circulation in the Northern Hemisphere mid-latitudes. Science, 348, 324-327.

Dai, A., K. E. Trenberth, and T.R. Karl, 1999: Effects of clouds, soil moisture, precipitation, and water vapor on diurnal temperature range. J. Climate, 12, 2451-2473.

Dole, R., and Coauthors, 2011: Was there a basis for anticipating the 2010 Russian heat wave? Geophys. Res. Lett., 38, L06702, doi:10.1029/2010GL046582.

Dong, B., R. T. Sutton, T. Woollings, and K. Hodges, 2013a: Variability of the North Atlantic summer stormtrack: Mechanisms and impacts. Environ. Res. Lett., 8, 034037, doi:10.1088/1748-9326/8/3/034037.

Dong, B.-W., R. T. Sutton, and T. Woollings, 2013b: The extreme European summer 2012 [in "Explaining Extreme Events of 2012 from a Climate Perspective"]. Bull. Amer. Meteor. Soc., 94 (9), S28-S32.

Dong, B.-W., R. T. Sutton, and L. Shaffrey, 2016: Understanding the rapid summer warming and changes in temperature extremes since the mid1990s over Western Europe. Climate Dyn., open access, doi:10.1007/s00382-016-3158-8.

Duchez, A., and Coauthors, 2016: Drivers of exceptionally cold North Atlantic Ocean temperatures and their link to the 2015 European heat wave. Environ. Res. Lett., 11, 074004, doi:10.1088/1748-9326/11/7/074004. 
Fischer, E. M., and C. Schär, 2010: Consistent geographical patterns of changes in high-impact European heatwaves. Nat. Geosci., 3, 398-403, doi:10.1038/ngeo866.

Haylock, M. R., N. Hofstra, A. M. G. Klein Tank, E. J. Klok, P. D. Jones, and M. New, 2008: A European daily high-resolution gridded dataset of surface temperature and precipitation for 1950-2006. J. Geophys. Res., 113, D20119, doi:10.1029/2008JD010201.

Hewitt, H. T., D. Copsey, I. D. Culverwell, C. M. Harris, R. S. R. Hill, A. B. Keen, A. J. McLaren, and E. C. Hunke, 2011: Design and implementation of the infrastructure of HadGEM3: The next-generation Met Office climate modelling system. Geosci. Model Dev., 4, 223-253, doi:10.5194/gmd-4-223-2011.

Kysely, J., and E. Plavcova, 2012: Biases in the diurnal temperature range in Central Europe in an ensemble of regional climate models and their possible causes. Climate Dyn., 39, 1275-1286, doi:10.1007/s00382 -011-1200-4.

Lamarque, J.-F., and Coauthors, 2010: Historical (1850-2000) gridded anthropogenic and biomass burning emissions of reactive gases and aerosols: Methodology and application. Atmos. Chem. Phys., 10, 7017-7039, doi:10.5194/acp-10-7017-2010.

Lamarque, J.-F., and Coauthors, 2011: Global and regional evolution of short-lived radiatively-active gases and aerosols in the Representative Concentration Pathways. Climatic Change, 109, 191-212, doi:10.1007/s10584-011-0155-0.

Liberto, T. D., 2015: Summer heat wave arrives in Europe. Climate.gov, 14 July 2015. [Available online at www.climate.gov/news-features/event-tracker /summer-heat-wave-arrives-europe.]

Miralles, D. G., A. J. Teuling, C. C. van Heerwaarden, and J. V. G. de Arellano, 2014: Mega-heatwave temperatures due to combined soil desiccation and atmospheric heat accumulation. Nat. Geosci., 7, 345-349.

Mueller, B., and S. I. Seneviratne, 2012: Hot days induced by precipitation deficits at the global scale. Proc. Natl. Acad. Sci. USA, 109, 12 398-12 403.

Ogawa, F., H. Nakamura, K. Nishii, T. Miyasaka, and A. Kuwano-Yoshida, 2012: Dependence of the climatological axial latitudes of the tropospheric westerlies and storm tracks on the latitude of an extratropical oceanic front. Geophys. Res. Lett., 39, L05804, doi:10.1029/2011GL049922.
Otto, F. E. L., N. Massey, G. J. van Oldenborgh, R. G. Jones, and M. R. Allen, 2012: Reconciling two approaches to attribution of the 2010 Russian heat wave. Geophys. Res. Lett., 39, L04702, doi:10.1029/2011GL050422.

Perkins, S.E., 2015: A review on the scientific understanding of heatwaves-Their measurement, driving mechanisms, and changes at the global scale. Atmos. Res., 164, 242-267, doi:10.1016/j.atmosres.2015.05.014.

Rayner, N. A., D. E. Parker, E. B. Horton, C. K. Folland, L. V. Alexander, D. P. Rowell, E. C. Kent, and A. Kaplan, 2003: Global analyses of sea surface temperature, sea ice, and night marine air temperature since the late nineteenth century. J. Geophys. Res., 108, 4407, doi:10.1029/2002JD002670.

Schaer, C., P. L. Vidale, D. Luethi, C. Frei, C. Haeberli, M. A. Liniger and C. Appenzeller, 2004: The role of increasing temperature variability in European summer heatwaves. Nature, 427, 332-336.

Vautard, R., and Coauthors, 2007: Summertime European heat and drought waves induced by wintertime Mediterranean rainfall deficit. Geophys. Res. Lett., 34, L07711, doi:10.1029/2006GL028001.

WMO, 2015: The state of greenhouse gases in the atmosphere based on global observations through 2014. WMO Greenhouse Gas Bulletin, No. 11, 4 pp. [Available online at www.wmo.int/pages/prog/arep /gaw/ghg/GHGbulletin.html.]

WMO, 2016: Exceptionally strong El Niño has passed its peak, but impacts continue. WMO Press Release 3, 18 February 2016. [Available online at www .wmo.int/media/content/exceptionally-strong -el-ni\%C3\%B1o-has-passed-its-peak-impacts -continue.] 


\section{Table 28.I. Summary of Results}

\section{ANTHROPOGENIC INFLUENCE ON EVENT}

\begin{tabular}{|c|c|c|c|}
\hline & INCREASE & DECREASE & NOT FOUND OR UNCERTAIN \\
\hline Heat & $\begin{array}{l}\text { Global Temperature (Ch. 2) } \\
\text { South India \& Sri Lanka (Ch. 2) } \\
\text { Central Europe (Ch. II) } \\
\text { Europe (Ch. I2) } \\
\text { Ethiopia and Southern Africa (Ch. I5) } \\
\text { N.W. China (Ch. I9) } \\
\text { W. China (Ch. 20) } \\
\text { Japan (Ch. 2I) } \\
\text { Indonesia (Ch. 22) } \\
\text { S. Australia (Ch. 23) } \\
\text { Australia (Ch. 24) }\end{array}$ & & Central Equitorial Pacific (Ch. 2) \\
\hline Cold & & Northeastern U.S. (Ch. 7) & $\begin{array}{l}\text { Mid-South Atlantic U.S. (Ch. 7) } \\
\text { N. America (Ch. 8) }\end{array}$ \\
\hline $\begin{array}{l}\text { Heat \& } \\
\text { Humidity }\end{array}$ & $\begin{array}{l}\text { Egypt (Ch. I4) } \\
\text { India \& Pakistan (Ch. 16) }\end{array}$ & & \\
\hline Dryness & $\begin{array}{l}\text { Indonesia (Ch. 22) } \\
\text { Tasmania (Ch. 25) }\end{array}$ & & \\
\hline $\begin{array}{l}\text { Heavy } \\
\text { Precipitation }\end{array}$ & China (Ch. 18) & & $\begin{array}{l}\text { Nigeria (Ch. I3) } \\
\text { India (Ch. I7) }\end{array}$ \\
\hline Sunshine & United Kingdom (Ch. I0) & & \\
\hline Drought & $\begin{array}{l}\text { Canada (Ch. 9) } \\
\text { Ethiopia and Southern Africa (Ch. I5) }\end{array}$ & & \\
\hline $\begin{array}{l}\text { Tropical } \\
\text { Cyclones }\end{array}$ & Western North Pacific (Ch. 26) & & \\
\hline Wildfires & Alaska (Ch. 4) & & \\
\hline $\begin{array}{l}\text { Sea Ice } \\
\text { Extent }\end{array}$ & & Arctic (Ch. 27) & \\
\hline $\begin{array}{l}\text { HIGH TIDE } \\
\text { FLOODS }\end{array}$ & SOUtheastern U.S. (CH. 6) & & \\
\hline $\begin{array}{l}\text { SNOWPACK } \\
\text { DROUGHT }\end{array}$ & WASHINGTON U.S. (CH. 5) & & \\
\hline TOTAL & 23 & 2 & 5 \\
\hline
\end{tabular}




\section{METHOD USED}

Heat

Heat \& Humidity

Dryness

Heavy

Precipitation

Sunshine

Drought

Tropical

Cyclones

Wildfires

Sea Ice

Extent

High TIDE

FLOODS

SNOWPACK

DROUGHT

\section{Ch. 2: CMIP5 modeling}

Ch. II: Observations; weather@home modeling

Ch. 12: HadGEM3-A modeling

Ch. 15: CMIP5 modeling

Ch. 19: CMIP5 modeling with ROF; FAR

Ch. 20: CMIP5 modeling with ROF; FAR

Ch. 21: MIROC5-AGCM modeling

Ch. 22: Observations; CMIP5 modeling

Ch. 23: weather@home modeling; FAR

Ch. 24: BoM seasonal forecast attribution system and seasonal forecasts

Ch. 7: Observations; CMIP5 modeling

Ch. 8: AMIP (IFS model) modeling

Ch. 14: weather@home modeling

Ch. 16: Non-stationary EV theory; C20C+ Attribution Subproject

Ch. 22: Observations; CMIP5 modeling

Ch. 25: Observations; Modeling with CMIP5 and weather@home

Ch. 13: Observations; Modeling with CAM5.I and MIROC5

Ch. 17: Observations; Modeling with weather@home, EC-Earth and CMIP5

Ch. 18: HadGEM3-A-N216 modeling; FAR

Ch. I0: Hadley Centre event attribution system built on the high-resolution version of HadGEM3-A

Ch. 9: Observations; CMIP5 modeling; Trend and FAR analyses

Ch. 15: CMIP5 modeling, land surface model simulations, and statistical analyses

Ch. 26: GFDL FLOR modeling; FAR

12

Ch. 4: WRF-ARW optimized for Alaska with metric of fire risk (BUI) to calculate FAR

Ch. 27: OGCM modeling

CH. 6: Tide-gauge data; Time-dependent EV statistical model

Ch. 5: Observations; CeSMI modeling 